\title{
The Help by Kathryn Stockett
}

\section{Reviewed by Heba Rajili}

Guest Lecturer, Women's Christian College, Chennai, India

Mail Id: rajiliheba@gmail.com | ORCID ID: 0000-0001-8670-7004

\author{
Bibliographic Information: \\ Name of the Book: The Help \\ Author: Kathryn Stockett \\ Publisher: Penguin; Media tie-in edition (13 May 2010) \\ Language : English \\ Paperback : 464 pages \\ ISBN-10: 0141039280 \\ ISBN-13: 978-0141039282 \\ INR 1770 (Hardcover) | INR 188 (Paperback) | \$9.6
}

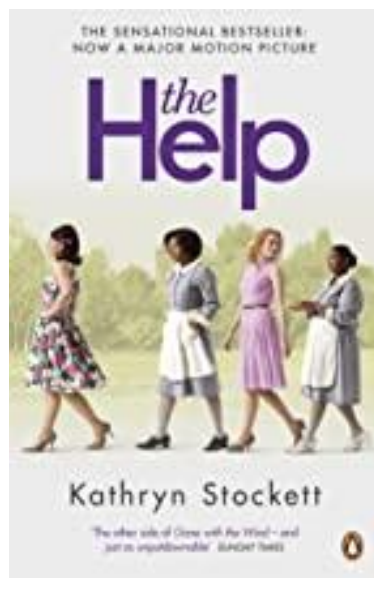

\begin{abstract}
About the Author: Kathryn Stockett was born and raised in Jackson, Mississippi. After graduating from the University of Alabama, she moved to New York City, where she worked in magazine publishing and marketing for nine years. She currently lives in Atlanta with her husband and daughter. This is her first novel.
\end{abstract}

Kathryn Stockett is an American writer whose book, The Help (2009) has become popular. The author dramatizes the problems that black women go through in their day to day life. For women of colour the oppression they face is double since it is by men in their own society and also by the white community due to their race. The Help remained a best seller and it was made into a film too. The novel was immensely popular with women.

The novel is set in 1962 during the nascent Civil Rights Movement in Jackson, Mississippi. Stockett invents three narrators who weave a story collectively focused on women. Skeeter is a young white woman who is deeply rooted in Jackson society and aspires to be a writer. Aibileen, is a domestic help who works in the house of Skeeter's friends and Minny, Aibileen's friend is an outspoken maid. There are two black narrators which Stockett uses but the lives of black people remain to be marginalised. This novel which became a featured film shows how white women must accept their participation in the indignity of segregation. Aibileen and Minny defy the notion that both black 
and white women are ignorant about each other's lives. In fact, black women know the lives of white women quite well and the lessons were taught to them by their own mothers (39).

The characters in the novel are divided into different racial camps but their speech pattern reveals the black difference in the novel. Even though the novel is set in Mississippi it is only the African American characters who use non Standard English. Here speech becomes an indication of racial difference. The difference is indicated in the way in which black bodies are represented. They are shown as being absent or large and dark. The black men are not seen as important human beings but Minny's husband Leroy is the only one who is given importance in the novel.

In the novel the action is focused on Hilly Holbrook's Home Help Sanitation Initiative which proposed separate washrooms for domestic workers. Here the black bodies were seen to be diseased but it ironical because the white people invite the black women to their homes to clean personal spaces, cook and take care of their children. The stories of these women in the town both black and white are all entwined together. The novel shows a time when there were social lines which could not be crossed and what happened when people dared to cross them. Stockett writes partly from her own experience of growing up in that place with a close relationship with her family's maid and so it can be seen as a memoir.

The novel shows the interaction between a white woman Skeeter Phelan and the black maids. After finishing her study Skeeter travelled to her hometown to find Constantine her favourite maid with whom she shared unforgettable memories. Skeeter worked as a journalist and wrote articles about maids and housekeeping and that led her to meet Aibileen, Minny and other black maids in the town. Aibileen was a black maid who worked for the Leefolts family as a nanny. She took care of a two year old baby girl called Mae Mobley Leefolts who loved Aibileen. Skeeter was Mae Mobley's mother's friend. Just like Aibileen, Minny also worked for a white family. She worked for Hilly Holbrook and was fired since she refused to use the black maid's toilet.

Hilly is another important character in the novel and she is Skeeter's childhood friend. Though they grew up together their perspectives about racism in Mississippi were different. Hilly was the leader of the Junior League and she held a prominent position among white women of the town. She told Skeeter that she was working on a project regarding the real condition of black maids in Jackson, Mississippi. The aim of the project proposed by Hilly was that white families should provide toilets for their black maids outside. Skeeter disagreed with Hilly's idea and she secretly sought Aibileen's help and asked if she also wanted to do something to reverse the condition. After completing the project Skeeter decided to publish it and when it was published it become popular in Jackson.

The novel as well as the film directed by Tate Taylor created controversy upon their release. The novel spent 100 weeks on the New York Times Best seller List and the screen adaptation was the thirteenth top engrossing film of 2011. The novel and the film recall several of the tropes that recur throughout many popular representations of the genre. They revolve around white characters and portray the racist behaviour especially between them and the black workers. 
The Help certainly invokes the American cultural memory of an earlier period and it also challenges the conventions of representing that period by foregrounding memories of black women. The novel focuses on the exploitation of black women and their experiences. When the novel and the film were released there were objections to it because it focused on the Civil Rights era. The readers and the audience were not happy when they saw or heard the outline of the story which is a story of a young white woman writing the stories of black women servants. Some readers and audience objected to the film since it focused on black women doing domestic work which they believed was a stereotypical role and it was inherently limiting.

The novel shows the way of living and the hardships the black women faced. Most of them were domestic help and they toiled hard without receiving any respect in return. The issues dealt with in this novel are relevant still because the problem of racism exists even now. Since the perspective of the black women is different from that of white women, seeing the world from the character's point of view helps the readers to experience that feeling. The book is divided into thirty four chapters and except chapter twenty five all the other chapters are narrated by Aibileen, Minny and Miss Skeeter. The Help features a young college educated, white woman who helps a community of black maids find their voices during the Civil Rights era in Jackson. Many critics felt that Stockett's novel displays the long standing white misunderstanding of the other in spite of intent to comprehend and do justice to the blacks. When writers use white conventions of race identity to personify the racial other what happens is they cause vexation to those who are targeted by these representations.

\section{Reviewer's details:}

Heba Rajili is a faculty from Women's Christian College, Chennai. She is interested in literary theories and is passionate about reading. Her areas of interest include Postcolonial Studies, Women's Writing and Travel Writing. She is interested in reading about emerging literary trends and theories which brings about changes in the process of thinking about a text. She also loves to review books. 